\title{
PENGARUH NET PROFIT MARGIN, DEBT TO EQUITY RATIO, DAN FIRM SIZE TERHADAP KEBIJAKAN DIVIDEND PAYOUT RATIO PADA PERUSAHAAN YANG TERDAFTAR DI BURSA EFEK INDONESIA
}

\author{
Irving Gregorius Mananta \\ Program Studi Magister Manajemen Universitas Tarumanagara \\ irvinggregoriusmananta@gmail.com
}

\begin{abstract}
Penelitian ini dilakukan untuk menguji pengaruh Net Profit Margin (NPM), Debt To Equity Ratio (DER), dan Firm Size (FS) terhadap kebijakan Dividend Payout Ratio (DPR). Sampel untuk penelitian ini diambil dengan menggunakan metode purposive sampling dari perusahaan dalam indeks IDX High Dividend 20 yang terdaftar di Bursa Efek Indonesia (BEI) periode 2015-2017. Sampel yang digunakan dalam penelitian berjumlah 60 sampel. Teknik analisis yang digunakan dalam penelitian adalah analisis regresi berganda. Hasil penelitian ini menunjukkan bahwa secara parsial, variabel Net Profit Margin (NPM) berpengaruh-terhadap variabel Dividend Payout Ratio (DPR), sedangkan variabel Debt To Equity Ratio (DER) dan Firm Size (FS) tidak berpengaruh terhadap variabel Dividend Payout Ratio (DPR). Secara simultan, terdapat pengaruh signifikan dari variabel Net Profit Margin (NPM), Debt To Equity Ratio (DER), dan Firm Size (FS) terhadap variabel Dividend Payout Ratio (DPR). Disarankan bagi investor maupun perusahaan untuk memperhatikan faktor Net Profit Margin (NPM) sebagai faktor yang amat menentukan dalam merancang kebijakan Dividend Payout Ratio (DPR).
\end{abstract}

Kata Kunci : Net Profit Margin (NPM), Debt To Equity Ratio (DER), Firm Size (FS), Dividend Payout Ratio (DPR)

\section{PENDAHULUAN \\ Latar Belakang}

Penerapan kebijakan perusahaan yang efektif dan efisien sangat dibutuhkan dalam menghadapi persaingan bisnis yang kian dinamis. Salah satu hal yang harus dipertimbangkan secara matang oleh manajemen perusahaan terkait dengan kebijakan pembagian dividen. Dividen merupakan pembayaran kepada pemegang saham oleh perusahaan atas keuntungan yang diperolehnya. Menurut Arilaha (2009), "kebijakan dividen suatu perusahaan akan melibatkan dua pihak yang berkepentingan dan saling bertentangan, yaitu kepentingan pemegang saham yang mengharapkan dividen, dengan kepentingan perusahaan terhadap laba ditahan. Besar kecilnya dividen yang akan dibayarkan perusahaan tergantung pada kebijakan dividen dari masing-masing perusahaan."

Kebijakan dividen perusahaan tercermin dalam rasio pembayaran dividen (Dividend Payout Ratio), yakni persentase laba yang dibagikan dalam bentuk dividen tunai. Dari sisi investor, terdapat faktor-faktor yang biasanya digunakan sebagai dasar dalam menetapkan pengambilan keputusan investasi di saham perusahaan tertentu, yakni dengan melihat $\mathrm{Net}$ Profit Margin (NPM), Debt To Equity Ratio (DER), dan Firm Size (FS) dari sebuah perusahaan yang dilihat dari laporan keuangan perusahaan yang dipublikasikan.

Penelitian ini menggunakan sampel laporan keuangan perusahaan dalam indeks IDX High Dividend 20 yang terdaftar di Bursa Efek Indonesia periode 2015-2017 untuk masa review 1 Agustus 2018-31 Januari 2019. Alasan penggunaan sampel perusahaan dalam indeks IDX High Dividend 20 karena perusahaan yang termasuk dalam indeks ini merupakan perusahaan dengan saham-saham yang tergolong Blue Chip atau yang memiliki kinerja mapan serta memiliki fundamental yang baik dan memiliki tingkat imbal hasil dividen (Dividend Yield) yang tinggi sehingga seringkali dilirik oleh investor. 


\section{Tujuan Penelitian}

Tujuan dari dilakukannya penelitian ini adalah untuk mengkaji pengaruh dari Net Profit Margin (NPM), Debt To Equity Ratio (DER), Firm Size (FS) secara parsial dan secara bersamasama (simultan) terhadap kebijakan Dividend Payout Ratio (DPR) pada perusahaan dalam indeks IDX High Dividend 20 yang terdaftar di Bursa Efek Indonesia periode 2015-2017.

\section{TINJAUAN PUSTAKA}

Net Profit Margin (NPM) merupakan salah satu dari rasio profitabilitas, yang berfungsi untuk menghitung sejauh mana kemampuan suatu perusahaan dalam menghasilkan laba bersih pada tingkat penjualan tertentu. Tingkat efisiensi dan efektifitas pengelolaan perusahaan dapat diketahui dengan membandingkan laba yang diperoleh dengan kekayaan atau modal yang menghasilkan laba tersebut. Semakin besar laba yang dihasilkan maka akan memberikan imbal hasil yang semakin maksimal bagi investor (Hanafi dan Halim, 2005, 86).

Net Profit Margin (NPM) dapat dirumuskan sebagai berikut:

$$
\mathrm{NPM}=\frac{\text { Net Income }(\mathrm{NI})}{\text { Total Sales }}
$$

Debt To Equity Ratio (DER) adalah rasio hutang terhadap modal. Rasio ini mengukur seberapa jauh perusahaan dibiayai oleh hutang, dimana semakin tinggi nilai rasio ini maka semakin menunjukkan gejala yang kurang baik pada perusahaan tersebut. Jumlah hutang yang semakin besar akan akan mempengaruhi jumlah laba bersih yang tersedia, termasuk dividen untuk para pemegang saham, sebab kewajiban membayar hutang menjadi lebih diprioritaskan dibanding pembayaran dividen (Sartono, 2001).

Debt To Equity Ratio (DER) dapat dirumuskan sebagai berikut:

$$
\text { DER }=\frac{\text { Total Liabilites }}{\text { Total Equity }}
$$

Firm Size (FS) merupakan suatu ukuran besar kecilnya suatu perusahaan yang dapat dilihat dengan besarnya nilai aktiva yang dimiliki perusahaan serta merupakan faktor penting dalam pengambilan keputusan investor untuk berinvestasi pada suatu perusahaan. Besar kecilnya aset yang dimiliki perusahaan berkaitan erat dengan tingkat pengembalian kepada investor (Samrotun, 2015, 95).

Firm Size dapat dirumuskan sebagai berikut:

$$
\text { Firm Size }=\text { Log of Total Asset }
$$

Dividend Payout Ratio (DPR) merupakan persentase laba yang dibagikan dalam bentuk dividen tunai, artinya besar kecilnya nilai DPR akan mempengaruhi keputusan investasi para pemegang saham dan di sisi lain juga mempengaruhi kondisi keuangan perusahaan. Penetapan kebijakan terkait dengan Dividend Payout Ratio (DPR) seringkali berkaitan dengan kinerja keuangan perusahaan. Jika kinerja keuangan perusahaan berada pada tingkat yang memuaskan, maka perusahaan dapat merancang kebijakan DPR yang berorientasi pada kepentingan pemegang saham, tanpa mengabaikan kepentingan perusahaan untuk terus maju (Marlina dan Danica, 2009).

Dividend Payout Ratio dapat dirumuskan sebagai berikut:

$$
\mathrm{DPR}=\frac{\text { Dividend yang dibayarkan }}{\text { Laba Bersih setelah Pajak }}
$$


Berdasarkan berbagai landasan teori tersebut maka dapat dibuat kerangka penulisan sebagai berikut:

Gambar 1

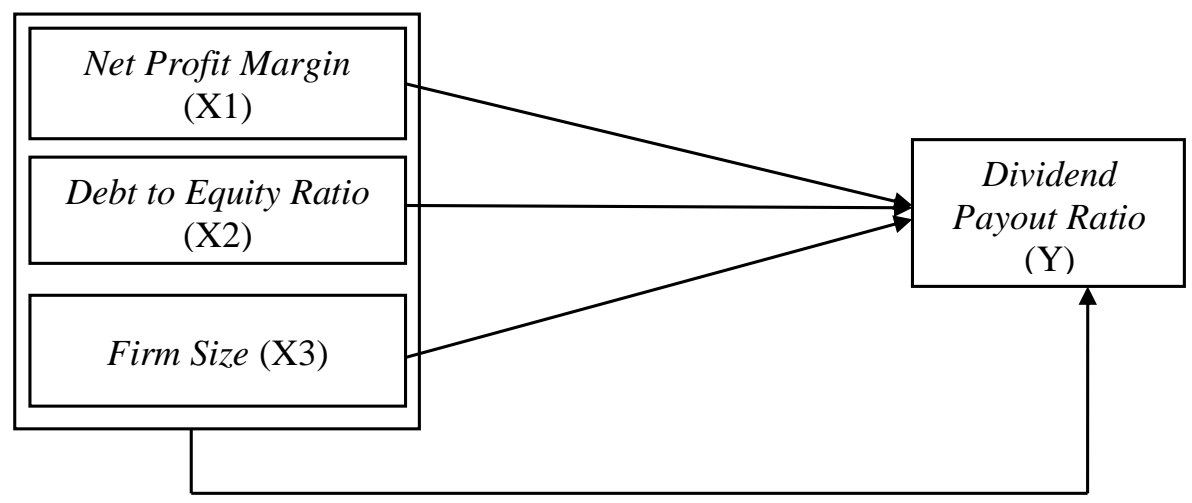

Berdasarkan kerangka pemikiran dan teori yang ada, maka hipotesis yang digunakan dalam penelitian ini adalah sebagai berikut:

Ha1 : Terdapat pengaruh signifikan dari Net Profit Margin (NPM) terhadap Dividend Payout Ratio (DPR) pada perusahaan dalam indeks IDX High Dividend 20 yang terdaftar di Bursa Efek Indonesia periode 2015-2017.

Ha2 : Terdapat pengaruh signifikan dari Debt To Equity Ratio (DER) terhadap Dividend Payout Ratio (DPR) pada perusahaan dalam indeks IDX High Dividend 20 yang terdaftar di Bursa Efek Indonesia periode 2015-2017.

Ha3 : Terdapat pengaruh signifikan dari Firm Size terhadap Dividend Payout Ratio (DPR) pada perusahaan dalam indeks IDX High Dividend 20 yang terdaftar di Bursa Efek Indonesia periode 2015-2017.

Ha4 : Terdapat pengaruh signifikan dari Net Profit Margin, Debt To Equity Ratio, dan Firm Size terhadap Dividend Payout Ratio (DPR) pada perusahaan dalam indeks IDX High Dividend 20 yang terdaftar di Bursa Efek Indonesia periode 2015-2017.

\section{METODE PENELITIAN}

\section{Jenis dan Sumber Data}

Penelitian ini merupakan jenis penelitian kausal. Penelitian Kausal merupakan penelitian yang mencari hubungan yang bersifat sebab akibat antara variabel independen dengan variabel dependen (Sugiyono, 2012, 37). Jenis data yang digunakan dalam penelitian ini adalah data sekunder, yakni data dari laporan keuangan perusahaan dalam Indeks IDX High Dividend 20 yang terdaftar di Bursa Efek Indonesia periode 2015-2017. Periode penelitian ini menggunakan data dari laporan keuangan perusahaan dalam Indeks IDX High Dividend 20 per 31 Desember dari tahun 2015-2017.

Data penelitian mengambil sumber dari data Bursa Efek Indonesia melalui situs www.idx.co.id. Metode pengambilan sampel menggunakan metode purposive sampling. Kriteria pengambilan sampel dalam penelitian ini adalah perusahaan dalam Indeks IDX High Dividend 20 yang terdaftar di Bursa Efek Indonesia periode 2015-2017, mempublikasikan laporan keuangan tahunan per 31 Desember dari tahun 2015-2017 secara berturut-turut, dan masuk kedalam Indeks IDX High Dividend 20 untuk masa review 1 Agustus 2018 - 31 Januari 2019.

\section{HASIL DAN PEMBAHASAN}

\section{Uji Normalitas}

Nilai probabilitas (p-value) yang dihasilkan dari pengujian normalitas sebesar 0.318326 , lebih besar dari nilai alpha 0.05 (0.318326 > 0.05). Maka dapat disimpulkan dari pengujian normalitas bahwa data berdistribusi normal. 


\section{Uji Multikolinearitas}

Berdasarkan hasil uji multikolinearitas, diperoleh hasil centered VIF dari variabel NPM, DER, dan FS yang seluruhnya kurang dari 10 (Nilai VIF < 10,00). Maka disimpulkan tidak terjadi multikolinearitas pada model regresi yang dilakukan.

\section{Uji Heteroskedastisitas}

Berdasarkan hasil uji heteroskedastisitas, diperoleh hasil F-Statistic sebesar 0.1091, lebih besar dari nilai alpha $0.05(0.1091>0.05)$. Maka disimpulkan tidak terjadi heteroskedastisitas pada penelitian ini.

\section{Uji t}

Uji t merupakan pengujian yang digunakan untuk mencari tahu apakah variabel independen secara parsial berpengaruh pada variabel dependen. Berikut ini adalah hasil uji $t$ penelitian ini yang ditampilkan dalam Tabel 1:

\section{Tabel 1}

\begin{tabular}{crrrr}
\hline \hline Variable & Coefficient & Std. Error & t-Statistic & Prob. \\
\hline \hline C & 12.62500 & 6.369772 & 1.982017 & 0.0549 \\
DER? & -0.105539 & 0.057486 & -1.835895 & 0.0744 \\
NPM? & -3.592087 & 0.817359 & -4.394747 & 0.0001 \\
FS? & -0.830724 & 0.471544 & -1.761711 & 0.0864
\end{tabular}

\begin{tabular}{llll}
\hline \hline & Weighted Statistics & \\
\hline \hline R-squared & 0.914049 & Mean dependent var & 1.201815 \\
Adjusted R-squared & 0.862943 & S.D. dependent var & 1.084173 \\
S.E. of regression & 0.254538 & Sum squared resid & 2.397207 \\
F-statistic & 17.88541 Durbin-Watson stat & 2.930700 \\
Prob(F-statistic) & 0.000000 & \\
\hline \hline
\end{tabular}

Berdasarkan hasil output dari Eviews 10, maka dapat diketahui:

1. Nilai signifikasi variabel Net Profit Margin (NPM) sebesar 0.0001 lebih kecil dari nilai $\alpha$ (alpha) $0.05(0.0001<0.05)$. Maka secara parsial terdapat pengaruh siginifikan antara variabel Net Profit Margin (NPM) terhadap variabel Dividend Payout Ratio (DPR).

2. Nilai signifikasi variabel Debt To Equity Ratio (DER) sebesar 0.0744 lebih besar dari nilai $\alpha$ (alpha) $0.05(0.0744>0.05)$. Maka secara parsial tidak terdapat pengaruh siginifikan antara variabel Debt To Equity Ratio (DER) terhadap variabel Dividend Payout Ratio (DPR).

3. Nilai signifikasi variabel Firm Size (FS) sebesar 0.0864 lebih besar dari nilai $\alpha$ (alpha) $0.05(0.0864>0.05)$. Maka secara parsial tidak terdapat pengaruh siginifikan antara variabel Firm Size (FS) terhadap variabel Dividend Payout Ratio (DPR).

\section{Uji F}

Nilai signifikasi (Prob F-statistic) sebesar 0.000000 lebih kecil dari nilai $\alpha$ (alpha) 0.05 $(0.000000<0.05)$. Maka terdapat pengaruh signifikan secara bersama-sama antara variabel Net Profit Margin (NPM), Debt To Equity Ratio (DER), dan Firm Size (FS) terhadap variabel Dividend Payout Ratio (DPR). 


\section{Uji Koefisien Determinasi}

Nilai adjusted $R$-Squared sebesar 0.862943 (86,29\%) menunjukkan persentase sumbangan pengaruh NPM, DER, dan FS terhadap kebijakan DPR sebesar 86,29\%.

\section{Pembahasan}

Net Profit Margin (NPM) memiliki pengaruh terhadap penetapan kebijakan Dividend Payout Ratio (DPR), hal ini selaras dengan teori yang menyatakan besarnya nilai laba bersih yang dihasilkan akan mempengaruhi nilai imbal hasil yang diberikan perusahaan kepada investor, yang tercermin dalam nilai DPR. Sedangkan Debt To Equity Ratio (DER) dan Firm Size (FS) tidak berpengaruh terhadap penetapan kebijakan Dividend Payout Ratio (DPR). Hal ini bertolak belakang dengan teori yang menyatakan kemampuan perusahaan dalam mengelola hutang jangka panjangnya mempengaruhi kebijakan DPR, serta besarnya jumlah aset yang dimiliki akan berpengaruh pada kebijakan DPR perusahaan.

\section{KESIMPULAN DAN SARAN Kesimpulan}

Secara parsial terdapat pengaruh signifikan dari Net Profit Margin (NPM) terhadap kebijakan Dividend Payout Ratio (DPR) pada perusahaan dalam indeks IDX High Dividend 20 yang terdaftar di Bursa Efek Indonesia periode 2015-2017. Sedangkan Debt To Equity Ratio (DER) dan Firm Size (FS) secara parsial tidak berpengaruh signifikan. Secara bersama-sama terdapat pengaruh signifikan dari Net Profit Margin (NPM), Debt To Equity Ratio (DER), dan Firm Size (FS) terhadap kebijakan Dividend Payout Ratio (DPR) pada perusahaan dalam indeks IDX High Dividend 20 yang terdaftar di Bursa Efek Indonesia periode 2015-2017.

\section{Saran}

Kepada investor maupun perusahaan disarankan untuk memperhatikan faktor-faktor yang dapat mempengaruhi kebijakan Dividend Payout Ratio (DPR), dimana dalam penelitian ini diketahui Net Profit Margin (NPM) menjadi faktor yang amat menentukan dalam merancang kebijakan Dividend Payout Ratio (DPR) perusahaan.

\section{Ucapan Terima Kasih}

Penulis mengucapkan terima kasih kepada keluarga serta berbagai pihak yang telah membantu dan memberikan dukungan dalam menyelesaikan penelitian ini. Selain itu penulis mengucapkan terima kasih kepada Jajaran Dosen dan Dosen Pembimbing di Universitas Tarumanagara Program Studi Magister Manajamen atas ilmu dan bimbingan yang telah diberikan kepada penulis.

\section{REFERENSI}

Arilaha, Muhammad Asril. 2009. Pengaruh Free Cash Flow, Profitabilitas, Likuiditas, dan Leverage terhadap Kebijakan Dividen. Jurnal Keuangan dan Perbankan: Vol. 13, No. 1. p. 78-87.

Hanafi, Mamduh M, dan Abdul Halim. 2005. Analisis Laporan Keuangan. Edisi 2. Yogyakarta: STIE YKPN.

Marlina, Lisa dan Clara Danica. 2009. Analisis Pengaruh Cash Position, Debt To Equity Ratio, dan Return on Assets terhadap Dividend Payout Ratio. Jurnal Manajemen Bisnis: Vol. 2, No. 1. p. 1-6.

Samrotun, Yuli Chomsatu. 2015. Kebijakan Dividend dan Faktor-Faktor yang Mempengaruhinya. Jurnal Paradigma: Vol. 13, No. 1.

Sartono, Agus. 2001. Manajemen Keuangan Teori dan Aplikasi. Yogyakarta: BPFE.

Sugiyono. 2012. Metode Penelitian Kuantitatif Kualitatif dan R\&D. Bandung: Alfabeta cv. www.idx.co.id 